\title{
STUDI HADIS PENDIDIKAN DI PERGURUAN TINGGI: REALITAS, PROBLEMATIKA DAN SOLUSI
}

\author{
Amrulloh \\ amrulloh985@gmail.com \\ Universitas Pesantren Tinggi Darul Ulum (Unipdu) Jombang \\ Mujianto Solichin \\ mujiantosolichin@fai.unipdu.ac.id \\ Universitas Pesantren Tinggi Darul Ulum (Unipdu) Jombang
}

\begin{abstract}
This research is motivated by a number of discrepancies between the reality of educational hadith quotation and the standard of the hadith quotation of the hadith. These divergences include the differences in the reference to educational hadith, assessment and process of understanding. This study aims to explain the motivation behind the citation of the educational hadith; classifying forms of educational hadith references, managing the validity of the educational hadith, categorizing the process of understanding the hadith; identifying the problems faced by educational hadith quoters, and then submiting the solution. This research applies integrative design between field research and library research. This study argues that the background of the educational hadith quotation revolves around the belief in the relevance between hadith and education; there are many discrepancies between the reality of the educational hadith quotation and the standard excerpt of the hadith; the problem of the educational hadith citation revolves around the ignorance of the hadith sciences and the difficulty of access to the primary reference to the hadith. This article then offers a solution that is to use the digital library of the hadith.
\end{abstract}

Keywords: Islamic Education, Hadith on Education, Hadith studies.

Abstrak: Penelitian ini dilatarbelakangi oleh banyaknya ketidaksesuaian antara realitas pengutipan hadis pendidikan dan standar pengutipan hadis dalam perspektif keilmuan hadis. Ketidaksesuaian itu meliputi perujukan, penilaian dan proses pemahaman hadis pendidikan. Penelitian ini bertujuan untuk menjelaskan motivasi yang melatarbelakangi pengutipan hadis pendidikan; mengklasifikasi bentuk rujukan hadis pendidikan, mengklasifikasi nilai hadis pendidikan, dan mengkategorisasi proses pemahaman hadis; mengidentifikasi problematika yang dihadapi pengutip hadis pendidikan, serta mengajukan tawaran solusinya. Penelitian ini menerapkan desain integrasi antara penelitian lapangan (field research) dan penelitian kepustakaan (library research). Hasil penelitian ini menunjukkan bahwa latar belakang pengutipan hadis berkisar pada keyakinan adanya relevansi antara hadis dengan konsep dan sistem pendidikan; banyak ketidaksesuaian antara realitas pengutipan hadis pendidikan dengan standar 
pengutipan hadis perspektif Ilmu Hadis; problem pengutipan hadis berkisar pada ketidakpahaman terhadap Ilmu Hadis dan susahnya akses rujukan primer kajian hadis, dan solusinya adalah pemanfaatan perpustakaan digital hadis.

Kata kunci: Pendidikan Islam, Hadis Tarbawi, Studi Hadis.

\section{Pendahuluan}

Banyak ketidaksesuaian antara realitas pengutipan hadis pendidikan yang ada dalam rujukan kajian hadis tarbaw $\bar{i}$ (pendidikan) dengan standar pengutipan hadis perspektif ilmu hadis. Imam Bawani, ${ }^{1}$ misalnya, menyebutkan hadis yang berbunyi: "Tuntutlah ilmu hingga ke Cina" (utlub al-ilm wa law bi al-sin) ${ }^{2}$ sebagai landasan teoritis. Mayoritas pakar hadis bersepakat menyematkan label "palsu" (mawd $\bar{u}$ ) untuk "hadis" tersebut, dan yang tidak termasuk dalam kategori mayoritas pun menilainya sebagai hadis yang sangat daif atau sangat lemah (da î jiddan). ${ }^{3}$ Intinya, "hadis" tersebut berstatus tertolak (mardūd) yang menyebabkan ia tidak layak dijadikan dasar argumentasi (bujjah). Di samping itu, penulisnya juga tidak merujukkan hadis tersebut kepada sumber aslinya. Tidak berbeda dengan itu, dalam buku Hadis Tarbawi yang notabene menjadi referensi utama tentang hadis-hadis pendidikan, Ahmad Falah menyebutkan kalimat "tuntutlah ilmu dari kandungan hingga liang lahat" (utlub al-ílm min almabd ila al-lahd) sebagai hadis Nabi. ${ }^{4}$ Padahal itu bukan hadis Nabi, melainkan kata bijak Aḥmad b. Hanbal (w. 241/855) dengan redaksi "belajarlah ilmu dari kandungan hingga liang lahat" (ta'allam al-ílm min al-mabd ila al-lahd $)^{5}$

Tulisan bebas yang bisa diakses dengan mudah lewat jaringan internet juga tidak jarang dijadikan referensi atau sekadar bacaan pendahuluan. Ini adalah konsekuensi perkembangan dan kemajuan

\footnotetext{
${ }^{1}$ Lihat Imam Bawani, Metodologi Penelitian Pendidikan Islam (Sidoarjo: Khazanah Ilmu, 2016).

2 Hadis palsu (maw $\bar{u} \bar{u}$ ) dari Anas b. Mālik: Aḥmad b. al-Husayn al-Bayhaqi, alMadkhal ilā al-Sunan al-Kubrä (Kuwait: Dār al-Khulafá' li al-Kitāb al-Islāmi, t.th), 241; Aḥmad b. al-Ḥusayn al-Bayhaqi, Shu'ab al-Imān (Riyad: Maktabat al-Rushd, 2003), 3: 193.

${ }^{3}$ Uraian komprehensif tentang status hadis ini bisa dilihat dalam penjelasan Nūr alDin 'Itr ketika mengomentarinya. Lihat al-Khațib al-Baghdādi, Al-Riḅlah fi $\bar{i}$ Ṭalab alHadith, ed. Nūr al-Dīn 'Itr (Beirut: Dār al-Kutub al-'Ilmìyah, 1975), 70-5.

4 Ahmad Falah, Hadis Tarbawi (Kudus: Noura Media Enterprise, 2010), 12-13.

${ }^{5}$ Lihat 'Abd al-Awwal b. Ḥammād al-Anșāīi, Al-Majmū' (t.tp: t.p, t.th), 2: 521.
} 
teknologi. Hanya saja, tulisan bebas yang tersebar luas di internet itu sering tidak memperhatikan reliabilitas dan validitas data yang disampaikan. Seorang blogger atas nama Rina Mubarok, misalnya, menyebarluaskan tulisan yang berjudul "kumpulan hadis-hadis tarbawi." Di dalamnya disebutkan kata-kata bijak yang berbunyi: "Jadilah orang yang berpengetahuan, orang yang belajar pengetahuan, orang yang mendengar pengetahuan atau orang yang cinta pengetahuan. Jangan menjadi yang kelima karena kamu akan celaka" (kun 'aliman aw muta'alliman aw mustami'an aw mubibban wa-là takun khamisan fa-tablika). ${ }^{6}$ Penulisnya menyebut kata-kata itu sebagai hadis Nabi. ${ }^{7}$ Padahal kata-kata itu bukan hadis, melainkan kata-kata bijak sahabat Nabi, yaitu Abū al-Dardā'. Di samping itu, penulisnya juga menyebutkan kata-kata bijak yang berbunyi: "Siapa mengharap dunia maka ia harus menuntut ilmu; siapa mengharap akhirat maka ia harus menuntut ilmu; dan siapa mengharap dunia akhirat ia juga harus menuntut ilmu" (man aräda al-dunyā fa 'alayh bi al-îlm wa man aräd aläkbirah fa 'alayh bi al-îlm wa-man arädahumā fa 'alayh bi al-ilm). ${ }^{8}$ Katakata ini disebut sebagai hadis riwayat al-Bukhäri (w. 256/870) dan

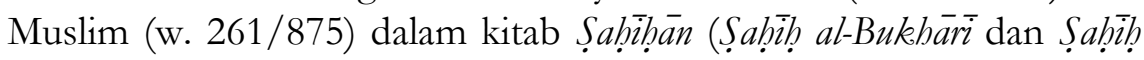
Muslim). Padahal kata-kata itu tidak ditemukan dalam seluruh kitab kompilasi hadis, termasuk kitab Șaḩiḩān. Tegasnya, kata-kata bijak itu bukan ucapan Nabi Muhammad, melainkan ucapan al-Shāfí̄i (w. 204/820) yang dikutip al-Nawawi (w. 676/1278). ${ }^{9}$

Demikian dari segi pengutipan yang berkaitan erat dengan perujukan dan penilaian hadis. Sedangkan dilihat dari segi pemanfaatan hadis untuk mendukung suatu teori atau konsep pendidikan, hadis terkadang masih dipahami secara tekstual bahkan terkadang radikal. Misalnya adalah hadis yang berbunyi: "Perintahkanlah anak untuk mengerjakan salat pada usia tujuh tahun, dan pukullah ia pada usia sepuluh tahun sebab meningalkan salat" (murū al-sabìy bi al-salāh idhā balagha sab' sinin, wa idhä balagha 'ashr sinin

${ }^{6}$ Bukan sebuah hadis, lihat al-Bayhaqii, Al-Madkhal ilä al-Sunan, 269.

7 Rima Mubarak, "Kumpulan Hadis-Hadis Tarbawi," dalam http://khairima.blogspot.co.id/2012/03/kumpulan-hadis-hadis-tarbawi.html.

Diakses pada 15 Februari 2015,

${ }^{8}$ Ibid.

${ }^{9}$ Lihat Yahyā b. Sharaf al-Nawawi, Al-Majmū' Sharh al-Mubadhdhab (Beirut: Dār alFikr, t.th), 1: 20. 
fadribūh 'alayha $\bar{a} .{ }^{10}$ Dalam sebuah situs Islami-internasional terkemuka yang bertajuk "Islam Question and Answer" (tanya-jawab Islami) yang diasuh oleh Mohammed Al Munajjed tentang pemahaman hadis tersebut, secara tekstual dan radikal tertulis:

"Pukulan merupakan salah satu sarana pendidikan. Sorang guru boleh memukul, seorang pendidik boleh memukul, orang tua juga boleh memukul sebagai bentuk pengajaran dan peringatan. Seorang suami juga boleh memukul isterinya apabila dia membangkang. Akan tetapi, hendaknya [pukulan itu] memiliki batasan. Misalnya, tidak boleh memukul [anggota tubuh] yang bisa membuat kulit lecet atau mematahkan tulang. Cukup pukulan seperlunya."11

Kesalahan-kesalahan fatal pengutipan hadis dalam tulisan-tulisan yang terhitung sebagai referensi pendidikan Islam, atau berpotensi sebagai referensi, ini merupakan kegelisahan akademik yang perlu segera ditangani dan diberikan solusi. Jika demikian keadaan referensireferensi yang ada, maka diasumsikan bahwa keadaan tesis dan skripsi tentang pendidikan yang merujuk pada referensi-referensi semacam itu juga ditemukan kesalahan-kesalahan fatal pengutipan hadis. Tujuan penelitian dengan lokasi Unipdu Jombang ini adalah menjelaskan motivasi-motivasi yang melatarbelakangi pengutipan hadis dalam tesis dan skripsi tentang pendidikan; mengklasifikasikan bentuk rujukan hadis-hadis yang dikutip; mengklasifikasikan nilai hadis-hadis yang dikutip; mengklasifikasikan bentuk proses pemahaman hadis-hadis yang dikutip; dan mengidentifikasi problematika yang dihadapi pengutip hadis pendidikan, serta mengajukan tawaran solusinya.

\section{Hadis Tarbawi: Sebuah Kerangka Teoretik}

Secara terminologis, al-Ṭaḥhān mendefinisikan hadis sebagai "perkataan, perbuatan, ketetapan atau sifat yang diasosiasikan kepada Nabi Muhammad."12 Dalam hadis terdapat nilai-nilai pendidikan yang bisa dikompromikan dengan konsep dan sistem pendidikan modern. Oleh karena itulah salah satu mata kuliah wajib di Program Studi Pendidikan Agama Islam adalah Hadis Tarbawi (pendidikan). Oleh karena itu pula banyak ditemukan referensi perkuliahan dengan tema

10 Hadis sahih dari Sabrah b. Ma`bad. Lihat, Abū Dāwud al-Sijistāni, Al-Sunan (Beirut: al-Maktabah al-'Așriyah, t.th), 1: 133.

11 "Bagaimana Caranya Memukul Anak yang Meninggalkan Salat," dalam https://islamqa.info/id/127233. Diakses pada 26 Februari 2017.

12 Maḥmūd al-Ṭaḥhān, Taysìr Muștalah al-Hadìth (t.tp: Maktabat al-Ma‘̄arif, 2004), 17. 
besar hadis seputar pendidikan atau pendidikan dalam perspektif hadis. Biasanya referensi-referensi itu diberi judul "Hadis Tarbawi." Di antara penulis referensi Hadis Tarbawi adalah Bukhari Umar, Abdul Majid Khon, Zaenal Efendi Hasibuan, Hasbiyallah dan Muhammad Sulhan, Alfiah dan Juwariyah. ${ }^{13}$

Di samping itu, banyak penelitian menyimpulkan bahwa sistem pendidikan modern yang ada saat ini bisa dikaitkan dengan hadis, dan demikian sebaliknya. Penelitian Hairudin menyimpulkan, setelah mengulas pendidikan karakter dalam perspektif hadis, objek pendidikan karakter adalah akidah atau keyakinan, adab atau etika, akal atau intelektualitas, jiwa, hidup sehat dan cinta ilmu pengetahuan. Pendidikan karekter itu bisa berhasil apabila dilakukan dengan: pendidikan dengan mendahulukan teladan (qudwab); pendidikan dengan habituasi; pendidikan dengan nasehat; dan pendidikan dengan evaluasi. ${ }^{14}$ Dalam kaitannya dengan karakter dan profesionalisme guru, penelitian Amrulloh menyimpulkan, para pendidik perlu merenungkan hadis "aku bagi kalian laksana ayah" (innamā anà lakum mithl al-wălid ${ }^{15}$ dalam mengembangkan potensi afektif. ${ }^{16}$

Tentang eksistensi nilai-nilai pendidikan dalam hadis, penelitian Ali menyimpulkan, di antara konsep pendidikan yang secara jelas bisa ditemukan dalam hadis adalah konsep pendidikan jasmani dan pendidikan sepanjang hayat (live long education).$^{17}$ Selanjutnya, penelitian Prabowo menyimpulkan bahwa banyak hadis bisa dikaitkan dengan konsep supervisi pendidikan agama Islam. $^{18}$ Lebih tegas lagi, penelitian Stapa, Yusuf dan Saharudin menyimpulkan, bagi umat Islam, Alquran dan Hadis harus dijadikan dasar dalam pendidikan

13 Muhammad Alfatih Suryadilaga, "Prospek Kajian Hadis di Perguruan Tinggi Keagamaan Islam di Indonesia," dalam Mutawatir Jurnal Keilmuan Tafsir Hadith, vol. 7, no. 1 (2017).

${ }^{14}$ Hairudin, "Pendidikan Karakter Berbasis Sunnah Nabi," dalam Jurnal al-Ulum: Jurnal Studi-Studi Islam, vol. 13, no. 1 (2013).

${ }^{15}$ Hadis sahih dari Abū Hurayrah. Lihat, Abū Dāwud, Al-Sunan, vol. 1, 3; Aḥmad b. Shu'ayb al-Nasāīi, Al-Sunan al-Sughrā, vol. 1 (Aleppo: Maktabat al-Maṭbüăt alIslāmiyyah, 1986), 38; Ibn Mājah al-Qazwinini, Al-Sunan, vol. 1 (t.tp: Dār Ihȳāa alKutub al-'Arabiyah, t.th), 114.

16 Amrulloh, "Guru Sebagai Orang Tua dalam Hadis 'Aku Bagi Kalian Laksana Ayah," dalam Dirasat: Jurnal Manajemen dan Pendidikan Islam, vol. 2, no. 1 (2016).

17 Nizar Ali, "Kependidikan Islam dalam Perspektif Hadis Nabi," dalam Jurnal Penelitian Agama, vol. 17, no. 1 (2008).

18 Yoga Sari Prabowo, "Supervisi Pendidikan Agama Islam: Kajian Alquran dan Hadis," dalam Edukasi: Jurnal Pendidikan Islam vol. 3, no. 1 (2015). 
masyarakat, sebab pendidikan dalam Islam mempunyai kaitan dengan aspek jasmani dan rohani: keduanya merupakan suatu bentuk kesatuan yang tidak dapat dipisahkan. ${ }^{19}$

Tentang manajemen pendidikan Islam, penelitian Amrulloh menyimpulkan bahwa ada sisi saling melengkapi antara hadis "jika suatu urusan diserahkan kepada selain ahlinya, maka tunggulah kehancuran" (idhā wussida al-amr ilà ghayr ablih fantaz̧ir al-sa'ab) ${ }^{20}$ dan salah satu 'mantra' manajemen modern, yaitu "the right man on the right job" (orang yang tepat harus berada pada pekerjaan yang tepat). ${ }^{21}$ Selanjutnya, penelitian Ma'ruf menyimpulkan, konsep manajemen secara eksplisit dan rinci memang tidak tertuang dalam Alquran dan Hadis. Namun, prinsip-prinsip manajemen, termasuk di dalamnya adalah manajemen pendidikan Islam, seperti perencanaan, pola kepemimpinan yang berkaitan dengan kehidupan organisasi, pelaksanaan dan evaluasi, tercantum dalam Alquran dan Hadis. ${ }^{22}$ Kesimpulan ini juga menguatkan kesimpulan penelitian yang dilakukan Hudaya sebelumnya. ${ }^{23}$ Jadi, hadis memang bisa dikaitkan dengan sistem dan konsep pendidikan modern. Sebaliknya, sistem dan pendidikan modern juga bisa didasarkan pada hadis. Asalkan hadis dipahami secara fleksibel dan kontekstual, hadis dan pendidikan modern bisa saling melengkapi dan menyempurnakan.

Dalam ilmu hadis terdapat istilah "takhrīj." Al- Ṭaḥhān mendefinisaikan takhrij dengan "menunjukkan lokasi hadis pada sumber aslinya yang mencantumkan hadis secara lengkap dengan sanadnya, serta menjelaskan nilai hadis jika diperlukan." ${ }^{24}$ Dilihat dari definisinya itu, takhrij mempunyai sejumlah indikator sebagai berikut.

19 Zakaria Stapa, Noranizah Yusuf dan Abdul Fatah Shaharudin, "Pendidikan Menurut Alquran dan Sunnah Serta Peranannya dalam Memperkasakan Tamadun Ummah," dalam Jurnal Hadhari: An International Journal (2012).

${ }^{20}$ Hadis sahih dari Abū Hurayrah. Lihat, Muhammad b. Ismā̄ill al-Bukhāri, Al-jāmi al-Ṣạih , vol. 1 (t.tp: Dār Tự al-Najāh, 1422 H), 21.

${ }^{21}$ Amrulloh, "Tawaran Komplementer Hadis Nabi untuk Gagasan 'The Right Man on the Right Job': Penelusuran dan Pemahaman Hadis 'Idhā Wussida al-Amr ila Ghayri Ablihi fa-Intażir al-Sā'ah,"' dalam Dirasat: Jurnal Manajemen dan Pendidikan Islam, vol. 1, no. 2 (2016).

${ }^{22}$ M. Ma'ruf, "Konsep Manajemen Pendidikan Islam dalam Alquran dan Hadis," dalam Didaktika Religia: Jurnal Pendidikan Islam, vol. 3, no. 2 (2015).

${ }^{23}$ Hairul Hudaya, "Prinsip-Prinsip Manajemen Pendidikan dalam Hadis," dalam $\mathrm{Al}$ Banjari: Jurnal Ilmiah Ilmu-Ilmu Keislaman, vol. 13, no. 2 (2014).

${ }^{24}$ Lihat Maḥmūd al-Ṭaḥ̣ān, Ușul al-Takhrīj wa Dirāsat al-Asānid (Riyad: Maktabat al$\mathrm{Ma}^{\circ}$ ärif, 1996), 10. 
Pertama, menunjukkan lokasi hadis. Ini dilakukan dengan menyebutkan judul kitab kompilasi hadis yang dikenal beserta nama

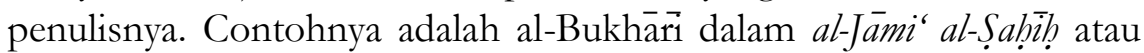
Șahịh al-Bukhäri dan Ahmad b. Hanbal (w. 241/855) dalam Al-Musnad. Kedua, merujukkan hadis kepada sumber aslinya dalam bentuk kitab kompilasi hadis (kutub al-sunnah). Kitab kompilasi hadis di sini ada tiga bentuk: (1) kitab kompilasi hadis yang disusun penulisnya dengan metode periwayatan dari perawi gurunya hingga Nabi Muhammad,

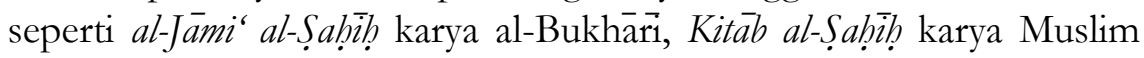
atau Șaḥiḥ Muslim, al-Musnad karya Aḥmad, dan masih banyak lagi; (2) kitab yang mengekor kepada kitab-kitab kompilasi hadis bentuk

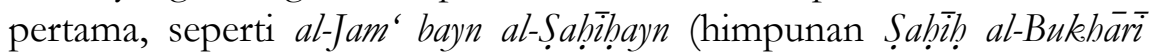
dan Sabịh Muslim) karya al-Humaydi (w. 488/1095); kitab kompilasi yang menghimpun potongan-potongan redaksi hadis, seperti Tuhfat alAshräf bi Ma'rifat al-Aträ́ karya al-Mizzi (w. 742/1341); (3) kitab yang merupakan penyederhanaan dari kitab-kitab kompilasi hadis bentuk

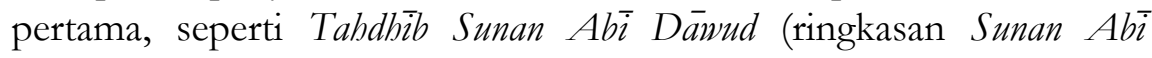
Dāwnd) karya al-Mundhirì (w. 656/1258). Standar rujukan yang biasa dan mudah digunakan adalah kitab kompilasi hadis bentuk pertama.

Ketiga, merujukkan hadis kepada sumber aslinya dalam bentuk non-kitab-kompilasi-hadis, seperti kitab-kitab dalam bidang tafsir, fikih dan sejarah. Dalam kitab-kitab semacam itu juga terdapat banyak hadis. Namun, penulis kitab-kitab itu harus meriwayatkan hadis yang ada dengan sanadnya sendiri dari perawi gurunya hingga Nabi Muhammad. Ini seperti Jämi' al-Bayān fī Tafsir al-Qur'an dan Tärikh alRusul wa al-Muluk karya al-Ṭabarì (w. 310/923), Al-Umm karya alShāfīi dalam bidang fikih, dan masih banyak lagi. Keempat, jika perlu, menjelaskan nilai hadis. Maksudnya, apakah hadis itu bernilai sahih, hasan, daif atau bahkan palsu. ${ }^{25}$

Takhrij mempunyai sejumlah fungsi. Di antara fungsi takhrij, seperti dikemukakan Jum'ah, adalah: (1) mengetahui sumber asli hadis; (2) mengetahui seluruh perawi hadis sekaligus kualitasnya (keadilan dan kedabitan); (3) menghimpun jalur sanad hadis, sehingga diketahui bentuk hadis dari segi kuantitas perawinya: apakah banyak (mutawatir) atau tidak banyak (ăhasd); (4) mengetahui apakah hadis mempunyai asal-usul ataukah tidak, sehingga diketahui apakah "hadis" tersebut dari Nabi Muhammad ataukah tidak; (5) mengetahui nilai

25 Ibid., 11. 
hadis: apakah diterima sebagai dasar argumentasi (maqbūt) ataukah ditolak (mardūd); (6) mengetahui naiknya nilai hadis berdasarkan banyaknya jalur sanad; (7) mengetahui kesalahan dan kekeliruan perawi. ${ }^{26}$

Ini adalah fungsi takbrij yang diharapkan jika dilakukan oleh peneliti Hadis. Di sini takbrij adalah langkah awal untuk menilai otentisitas dan validitas Hadis. Setelah men-takbrij 40 hadis pedoman NU karya Hasyim Asy'ari, misalnya, Su'aidi menemukan bahwa terdapat 5 hadis bernilai lemah (da if $)$ dan tidak bisa diangkat ke nilai yang lebih tinggi: sahih atau hasan. ${ }^{27}$ Fauziyah, dalam penelitiannya terhadap buku Pendidikan Agama Islam dan Budi Pekerti Kurikulum 2013 SMP kelas VII, setelah melakukan takbrij juga menemukan bahwa dari 19 hadis yang tercantum, terdapat 5 hadis yang bernilai lemah (da iff). ${ }^{28}$ Jika dilakukan oleh pengutip hadis, fungsi yang diharapkan adalah poin pertama dan keempat. Sedangkan fungsifungsi yang lain bisa digali dari pendapat para pakar hadis yang berkompeten di bidangnya.

Tentang hadis sahih, Ibn al-Ṣalạ̄ (w. 643/1245) dan al-Nawawi (w. 676/1278) mengajukan definisi yang berbeda. Ibn al-Ṣalạ̄ menyatakan, "Adapun yang disebut hadis sahih adalah hadis yang bersambung sanadnya sampai kepada Rasulullah, yang diriwayatkan oleh perawi adil dan dabit dari perawi yang adil dan dabit juga, dari awal sanad hingga akhirnya, dan ia tidak menyimpang (shädh) dan tidak juga bermasalah (mu'alla)." "29 Al-Nawawi menyatakan, "hadis sahih adalah hadis yang bersambung sanadnya, dengan diriwayatkan oleh perawi-perawi adil dan dabit, serta tidak mengandung penyimpangan (shudhüdh) dan tidak juga mengandung masalah

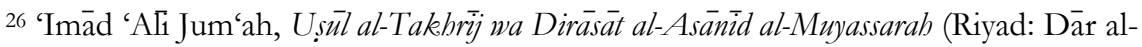
Nafa'is, 2004), 5. Lihat juga Jon Pamil, "Takhrij Hadis: Langkah Awal Penelitian Hadis," dalam Jurnal Pemikiran Islam, vol. 37, no. 1 (2013).

${ }^{27}$ Hasan Su'aidi, “40 Hadis Pedoman NU Karya K.H. Hasyim Asy'ari: Studi Takhrij dan Analisis Konteks Sosial Keagamaan Berdirinya NU," dalam Jurnal Penelitian, vol. 11, no. 1 (2014).

${ }^{28}$ Malihatul Fauziyah, "Takhrij Hadith dalam Buku Pendidikan Agama Islam dan Budi Pekerti Kurikulum 2013 SMP Kelas VII," dalam Didaktika Religia: Jurnal Pendidikan Islam, vol. 2, no. 2 (2014).

29 'Uthmān b. 'Amrū (Ibn al-Ṣalāh), Muqaddimat Ibn al-Ṣalāh (Beirut dan Suriah: Dār al-Fikr dan Dār al-Fikr al-Mu'àșir, 1986), 11.
} 
('illab)." ${ }^{30}$ Definisi kedua pakar hadis ini biasanya dikutip dan ditegaskan para pakar hadis yang sedang membahas standar hadis sahih. Di antara mereka adalah al-Mundhiri (w. 656/1258), Ibn Daqiq (w. 702/1302), Ibn Kathir (w. 774 H), al-Abnāsi (w. 802/1399), alȘancani (w. 1182/1768), al-Biqāīi (w. 885/1480), Ibn al-Mulaqqin (w. 804/1401), al-Suyuțī (w. 911/1505), Abū Shuhbah, dan Khalifah. ${ }^{31}$ Dalam kajiannya, Mohamed Nor menyatakan bahwa definisi Ibn alȘalāh yang tercantum dalam kitab Ulum al-Ḥadith (al-Muqaddimah), yang ditopang oleh al-Nawawi, inilah yang dikenal dalam penelitian konvensional hadis. ${ }^{32}$

Dengan demikian standar kesahihan hadis ada lima: sanad hadis tersambung; perawi hadis bersifat adil; perawi hadis bersifat dabit; hadis terbebas dari penyimpangan (shudhüdh); dan hadis terbebas dari masalah ('illah). Namun, menurut penelitian Syuhudi, standar mayor kesahihan hadis hanya tiga, yaitu standar pertama, kedua dan ketiga. Sedangkan standar keempat dan kelima adalah standar minor yang termasuk ke dalam standar mayor yang ketiga. Perincian standar mayor dan standar minor adalah sebagai berikut. Pertama, sanad hadis tersambung. Indikator ketersambungan sanad adalah bahwa ketersambungan itu ada pada awal sanad hingga akhir sanad (muttasil atau mawsūi); matan hadis diasosiasikan kepada Nabi Muhammad (marfú $)$; sanad dan matan hadis tidak mengandung penyimpangan

${ }^{30}$ Muhy al-Din al-Nawawi, Al-Taqrib wa-al-Taysir li-Ma'rifat Sunan al-Bashir al-Nadhìr fi Ușü al-Ḥadith (Beirut: Dār al-Kitāb al-'Arabi, 1985), 25.

${ }^{31}$ Lihat 'Abd al-'Ażim b. 'Abd al-Qawi al-Mundhiri, Jawāb al-Hệąiz al-Mundhiri 'an As'ilah fi al-Jarh wa al-Ta'dil (Halab: Maktabat al-Matbu'àt al-Islāmiyah, t.th), 44; Ibn

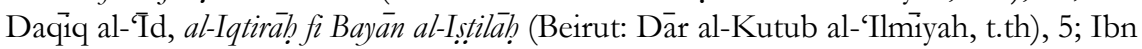

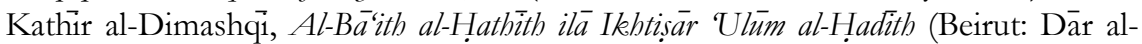
Kutub al-'Ilmiyah, t.th), 21; Al-Abnāsi, Al-Shadha al-Fayāh min 'Ulüm Ibn al-Salāh, vol. 1 (t.tp: Maktabat al-Rushd, 1998), 66; Muhammad b. Ismā̄il al-Ṣan'ani, Tawdīh al-Afkear li Máāni Tanqūh al-Anzāar, (Beirut: Där al-Kutub al-'Ilmiyyah, 1997), 17;

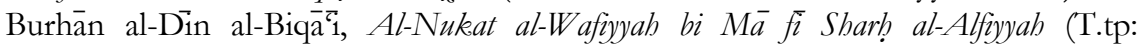
Maktabat al-Rushd, 2007), 79; Ibn al-Mulaqqin, Al-Muqni' fi 'Ulüm al-Hẹadith, 41; Jalāl al-Dìn al-Suyūți, Tadrīb al-Rāwī fi Sharḥ Taqrib al-Nawawi (t.tp: Dār Tịibah, t.th), 61; Muhammad b. Muḥammad Abū Shuhbah, al-Wasit fì 'Ulüm al-Ḥadith, 225; Muḥammad Rashād Khalifah, Madrasat al-Hadith fí Misr (Kairo: al-Hay'ah al'Āmmah li Shu'ūn al-Mațābi' al-Amiriyah, t.th), 418.

32 Zulhilmi bin Mohamed Nor, "Metodologi al-Ḥâfiz Ibn al-Ṣalāh dalam Permasalahan Pentashihan Hadis dan Fenonemana Pentashihan dalam Masa Kini," dalam Journal of Hadith Studies, vol. 1 (2016), 22. 
(mahfus); sanad dan matan hadis tidak mengandung masalah (ghayr mu'allal). Kedua, perawi hadis bersifat adil. Indikator keadilan perawi adalah beragama Islam; mukalaf; melaksanakan ketentuan agama; dan memelihara integritas diri (murüab). Ketiga, perawi bersifat dabit. Indikator kedabitan perawi adalah menghafal dengan baik hadis-hadis yang diriwayatkannya; mampu dengan baik menyampaikan hadishadis yang dihafalnya kepada orang lain; terhindar dari penyimpangan (shudhüdh) dalam konteks periwayatan hadis; terhindar dari masalah (illah) dalam konteks periwayatan hadis. ${ }^{33}$

Ini adalah standar hadis sahih konvensional yang diterapkan hingga saat ini, seperti yang dilakukan Asni, Sulong dan Ismail ketika mengidentifikasi penggunaan hadis daif dalam fatwa mengenai wasiat di Malaysia. ${ }^{34}$ Di bawah derajat hadis sahih ada hadis hasan yang bisa dijadikan dasar argumentasi (bujjah) layaknya hadis sahih, walaupun strata nilai hadis hasan di bawah nilai hadis sahih. Hadis hasan, seperti disimpulkan al-Ṭaḥ̣ān dari definisi-definisi pakar hadis terdahulu, adalah "hadis yang sanadnya tersambung dan diriwayatkan oleh perawi-perawi adil namun kedabitannya tidak terlalu kuat, dari awal sanad hingga akhir sanad, tanpa mengandung penyimpangan (shudhüdh) maupun masalah (illah)." ${ }^{35}$ Jadi perbedaan antara hadis sahih dan hadis hasan terletak pada kuat atau tidaknya kedabitan perawi, bukan ada atau tiadanya kedabitan. Hadis yang diterima (maqbü) dan tidak ditolak (mardüd) sebagai dasar argumentasi harus memenuhi standar hadis hasan. Namun ini memerlukan penelitian yang mendalam dan melelahkan. Oleh karena itu, nilai sahih, hasan dan daif dari suatu hadis bisa merujuk pada penilaian pakar hadis. Tentunya, itu dilakukan setelah melakukan penelaahan penilaianpenilaian pakar hadis, dan melakukan komparasi jika terdapat perbedaan penilaian di antara mereka.

Teori pemahaman hadis banyak ditemukan dalam karya-karya para pemikir Muslim, baik klasik seperti Ibn Qutaybah (w. 276/889) dan al-Shāfí̄i (w. 204/820) maupun modern seperti Fazlur Rahman (1919-1988) dan Muhammad al-Ghazāli (1917-1996). Namun di sini

\footnotetext{
${ }^{33}$ M. Syuhudi Ismail, Kaidah Kesabihan Sanad Hadis: Telaab Kritis dan Tinjauan dalam Ilmu Sejarah (Jakarta: Bulan Bintang, 2005), 155-6.

${ }^{34}$ Fathullah Al Haq Muhamad Asni, Jasni Sulong dan Ammar Ismail, "Penggunaan Hadis Daif dalam Fatwa Mengenai Wasiat di Malaysia serta Langkah Penyelesaiannya," dalam Journal of Hiadith Studies, vol. 2, no. 1 (2017).

35 Al-Ṭaḥhān, Taysìi Muștalah, 58.
} 
penulis lebih memilih pemikiran Yúsuf al-Qaraḍāwi dengan delapan metodenya dalam pemahaman hadis. Sebab, ia, dalam pandangan penulis, merupakan penengah antara pemikiran kiri dan pemikiran kanan dalam dunia pemikiran Islam. Sebelumnya, Safian menggarisbawahi bahwa metodologi dan pendekatan fikih, pemahaman hadis termasuk di dalamnya, Yüsuf al-Qaraḍāivi dikenal dengan kemoderatannya (manhaj wasat) dalam penyimpulan Syariat. ${ }^{36}$

Delapan metode pemahaman hadis versi Yùsuf al-Qaradāwi bisa disederhanakan sebagai berikut. ${ }^{37}$ Pertama, memahami hadis di bawah naungan Alquran (fahm al-sunnah $\bar{f} \bar{i} d \bar{u}$ al-Qur'an al-karim). Implikasi metode pertama ini adalah penegasan kedaifan hadis-hadis yang substansinya berseberangan dengan Alquran. Kedua, menghimpun

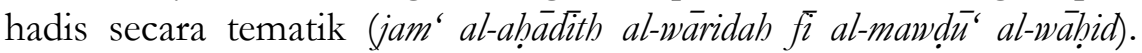
Implikasi metode kedua ini adalah bahwa secara tekstual satu hadis terkadang belum bisa menunjukkan satu hukum tertentu sebelum penelaahan hadis-hadis lain yang setema. Ketiga, mengompromikan hadis-hadis yang tampak kontradiktif (al-jam' aw al-tarīị bayn mukbtalif al-hadith). Implikasi dari metode ketiga ini adalah bahwa hadis-hadis yang tampak kontradiktif satu sama lain itu tetap diterapkan dalam konteksnya masing-masing. Keempat, memahami hadis berdasarkan latar belakang, situasi dan kondisi, serta tujuan prinsipnya (fahm al-

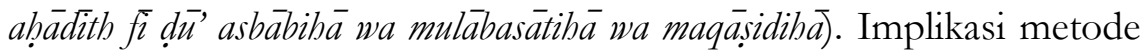
keempat ini adalah bahwa hadis terkadang harus dipahami secara kontekstual, bukan tekstual. Kelima, membedakan antara perantara yang bersifat kondisional dan tujuan yang bersifat permanen (al-tafriq bayn al-wasilah al-mutaghayyarah wa al-hadf al-thäbit li al-ḥadith). Implikasi metode kelima ini, selain kontekstualisasi pemahaman, adalah pengembangan tekstualitas perantara yang tercantum dalam suatu hadis sesuai dengan situasi dan kondisi yang ada. Keenam, membedakan antara yang hakiki dan yang majasi (al-tafriq bayna alhaqiqah wa al-majā fi fahm al-hadith). Implikasi metode keenam ini adalah bahwa ungkapan-ungkapan majasi dalam suatu hadis tidak bisa dipahami secara harfiah. Ketujuh, membedakan antara yang gaib dan

3636 Yasmin Hanani Mohd Safian, "The Contribution of Yūsuf al-Qaradāwi to the Development of Fiqh," dalam Electronical Journal of Islamic and Middle Eastern Law, vol. 4 (2016), 46.

37 Yüuf al-Qaraḍ̄āie, Kayf Nata'ämal ma' al-Sunnab al-Nabawīyab (Kairo: Dār alShurūq, 2002), 111-200. 
yang nyata (al-tafriq bayn al-ghayb wa al-shahädab). Implikasi dari metode ketujuh ini adalah bahwa pemahaman hadis-hadis yang bersifat gaib, seperti alam kubur, alam barzakh, surga, neraka dan lain sebagainya, harus dikembalikan pada kegaibannya. Kedelapan, memastikan maksud kata-kata hadis (al-ta'akkud min madlülat alfä al-hadith). Implikasi dari medote terakhir ini adalah bahwa maksud kata-kata yang dipakai dalam suatu hadis bisa jauh berbeda dengan maksud kata-kata yang sama yang telah menjadi peristilahan modern.

Dalam suatu kajian ilmiah, Ramle, Maiddin dan Abdul Hadi, menyimpulkan bahwa kontekstualisasi pemahaman adalah unsur terpenting yang bisa mengantarkan seseorang kepada pemahaman hadis secara tepat dan proporsional. Mereka juga menekankan bahwa salah satu pelopor awal metode kontekstualisasi pemehaman hadis, yang tidak bisa diabaikan, adalah Yūuf al-Qaraḍāwi. ${ }^{38}$ Sebelumnya, kesimpulan ini juga ditekankan oleh Dakir dan Ahmad Shah. ${ }^{39}$

\section{Overview tentang Metode dan Subjek}

Tulisan ini merupakan hasil dari penelitian kualitatif dan integrasi antara penelitian lapangan (field research) dan penelitian kepustakaan (library research). Penelitian lapangan berfungi untuk menggali dan menghimpun data tentang motivasi-motivasi yang melatarbelakangi pengutipan hadis dalam tesis dan skripsi tentang pendidikan serta problematika pengutipannya. Sedangkan penelitian kepustakaan berfungsi untuk menggali dan menghimpun data tentang bentuk perujukan, penilaian, dan proses pemahaman hadis. Sumber data penelitian lapangan diperoleh lewat observasi, wawancara dan studi dokumen, yang disebut Sugiyono sebagai teknik umum penggalian data kualitatif. ${ }^{40}$ Subjek wawancara dan observasi adalah personapersona yang terhitung sebagai pemangku kebijakan di tingkat Program Pascasarjana, Fakultas, Program Studi, dewan dosen dan penulis tesis dan skripsi tentang pendidikan.

Penggalian dan pengumpulan data tentang motivasi-motivasi yang melatarbelakangi pengutipan hadis pendidikan serta

38 Muhamad Rozaimi bin Ramle, Sahul Hamid bin Mohamed Maiddin dan Ahmad Zulfiqar Shah Abdul Hadi, "Fahm al-Ḥadith al-Sharif fí Ḍ̣'i al-Siyāq al-Zamani wa al-Tärikhi," dalma Journal of Hadith Studies, vol. 2, no. 1 (2017).

${ }^{39}$ Jawiah Dakir dan Faisal Ahmad Shah, "A Contextual Approach in Understanding The Prophet's Hadith: An Analysis," dalam Journal of Applied Science Research, vol. 8, no. 7 (2012).

${ }^{40}$ Sugiyono, Memahamai Penelitian Kualitatif (Bandung: Alfabeta, 2013), 63. 
problematikanya, dilakukan dengan metode observasi dan wawancara dengan subjek pemangku kebijakan, seperti Direktur Program Pascasarjana, Kepala Program Studi Manajemen Pendidikan Islam, Dekan Fakultas Agama Islam, Wakil Dekan Fakultas Agama Islam Bidang Akademik, Kepala Program Studi Pendidikan Agama Islam, para dosen yang terlibat secara langsung dalam pengajaran mata kuliah Hadis Tarbawi, dan para penulis tesis dan skripsi yang sudah dinyatakan lulus. Untuk menunjang data yang dihasilkan dari teknik observasi dan wawancara, teknik studi dokumen juga dimanfaatkan. Dokumen-dokumen yang relevan untuk ditelaah di sini, misalnya, adalah jurnal dosen pada mata kuliah Hadis Tarbawi, soal ujian sekaligus jawabannya.

Untuk menghimpun dan sekaligus menguji reliabilitas data, penulis juga mengaplikasikan metode triangulasi. Triangulasi, seperti ditegaskan Sugiyono, adalah "penggunaan teknik pengumpulan data yang berbeda-beda untuk mendapatkan data dari sumber yang sama." Di sini penulis akan memadukan teknik observasi, wawancara dan studi dokumen untuk diterapkan pada unit sumber yang sama guna menjaring data yang bisa dipertanggungjwabkan reliabilitasnya. Data yang yang dimaksudkan itu meliputi data tentang motivasi-motivasi yang melatarbelakangi pengutipan hadis pendidikan, serta problematika-problematika yang dihadapi para pengutipnya.

Data tertulis tentang bentuk perujukan, penilaian dan proses pemahaman hadis pendidikan digali dan dihimpun lewat penelitian kepustakaan. Walaupun terhitung sebagai sumber sekunder sebab bukan berupa kata-kata dan tindakan, Lexy J. Moleong tetap menekankan bahwa sumber tertulis tidak bisa diabaikan, ${ }^{41}$ lebih-lebih dalam penelitian di mana pengutipan hadis menjadi objek utamanya ini. Sumber tertulis penelitian kepustakaan di sini adalah arsip-arsip tesis dan skripsi tentang pendidikan yang tersimpan rapi di perpustakaan Unipdu Jombang. Pendidikan di sini meliputi skripsi Program Studi Pendidikan Agama Islam dan tesis Program Studi Manajemen Pendidikan Islam.

Dalam pengolahan data, penelitian ini menerapkan metode yang ditawarkan Miles dan Huberman, yaitu reduksi data (data reduction), penyajian data (data display) dan penarikan kesimpulan dan verifikasi

${ }^{41}$ Lexy J. Moleong, Metodologi Penelitian Kualitatif(Bandung: Rosda, 2013), 159. 
(conclusion drawing and verification). ${ }^{42}$ Dengan metode pengolahan tersebut, seluruh data tentang motivasi-motivasi yang melatarbelakangi pengutipan hadis dalam tesis dan skripsi tentang pendidikan di Unipdu Jombang, tentang rujukan, validitas, otentisitas dan pemanfaatan hadis, serta tentang problematika pengutipan yang dihadapi penulisnya, akan dihimpun dan diseleksi. Data yang telah terhimpun dan terseleksi dengan baik itu kemudian akan dideskripsikan apa adanya. Dengan metode wawancara yang ditambah dengan observasi dan studi dokumen di penelitian lapangan, serta dipadukan dengan studi arsip di penelitian kepustakaan, akan dijaring keterangan yang melimpah. Dengan penerapan metode reduksi data, tentunya tidak seluruh keterangan itu akan dimanfaatkan. Keterangan yang dimanfaatkan terbatas hanya pada data yang mempunyai relevansi secara langsung dengan analisis objek kajian, yaitu motivasimotivasi yang melatarbelakangi pengutipan hadis dalam tesis dan skripsi tentang pendidikan di Unipdu Jombang, validitas dan pemanfaatannya, serta problematika pengutipan yang dihadapi penulisnya. Selanjutnya data tersebut juga harus reliabel, objektif dan eksplisit. Data yang terhimpun dan telah melalui proses reduksi tersebut akan disajikan, dan ditarik kesimpulannya.

Penelitian ini termasuk dalam kategori studi agama (religious studies). Objek utama penelitian ini adalah hadis dalam arti perkataan dan perbuatan Nabi Muhammad. Dengan demikian, salah satu dari aneka pendekatan studi agama yang relevan di sini adalah pendekatan teologis yang dikembangkan Frank Whaling. Tentang teologi, Whaling menyimpulkan tiga hal: teologi pasti berkaitan dengan Tuhan dan transendensi, baik secara mitologis, filosofis ataupun dogmatis; doktrin adalah elemen paling signifikan dalam memaknai teologi; teologi sebenarnya adalah aktivitas lanjutan (second order activity) yang terinspirasi dari keimanan dan penafsiran atas keimanan..$^{43}$ Dengan demikian, pendekatan teologis berguna untuk menganalisis motivasimotivasi yang melatarbelakangi pengutipan hadis dalam tesis dan skripsi tentang pendidikan di Unipdu Jombang. Dalam pandangan kaum santri secara umum, hadis adalah teks yang bersifat transenden

42 Matthew B. Miles dan A. Michael Huberman, Qualitative Data Analysis: An Expanded Sourcebook (London: Sage Publication, 1994), 10-11.

43 Lihat Frank Whaling, "Pendekatan Teologis", dalam Aneka Pendekatan Studi Agama, ed. Peter Connolly (Yogyakarta: LKis, 2012), 319. Bandingkan dengan David F. Ford, "Theology", dalam The Routledge Companion to the Study of Religion, ed. John R. Hinnells (New York: Routledge, 2005), 61-79. 
sebagai akibat dari doktrin-doktrin agamawi yang bersifat dogmatis. Pada gilirannya, sifat transenden itu memotivasi praktik sakralisasi hadis dalam bentuk pencatutannya dalam segala aspek kehidupan, termasuk aspek pendidikan formal maupun lebih-lebih pendidikan informal.

Adapun bentuk perujukan, penilaian dan proses pemahaman hadis serta problematika yang dihadapi pengutip hadis pendidikan dianalisis menggunakan pendekatan takbrij, pendekatan kritik hadis dan pendekatan kontekstual dalam pemahaman hadis yang ditawarkan Yūsuf al-Qaraḍ̄âi. Takhrij dan pemahaman hadis model Yüsuf alQaraḍ̄āi telah dipaparkan sebelumnya. Sedangkan kritik hadis (naqd al-ḥadith), seperti ditulis al-A'zami, adalah "proses penyaringan hadis supaya diketahui kesahihan atau kedaifannya, serta proses penilaian perawi supaya diketahui keterpercayaan (ke-thiqab-an) atau kedaifannya." "Proses penyaringan hadis supaya diketahui kesahihan atau kedaifannya," yakni diterimanya (maqbüh) atau ditolaknya (mardūd) sebagai dasar argumentasi (bujjab), diimplementasikan secara sederhana. Jika satu hadis dinilai diterima, berarti ia telah memenuhi standar validitas hadis. Jika suatu hadis dinilai ditolak, alasan penolakan itu dijelaskan secara sederhana. Dalam pelacakan dan penelusuran hadis maupun perawi-perawinya, penulis memanfaatkan perangkat lunak Maktabah Shämilah versi dan update terbaru. Perangkat lunak yang penomorannya, seperti penomoran volume dan halaman, telah disesuaikan dengan kebutuhan pengutipan referensi itu efektif dan efisien untuk melacak dan menelusuri hadis sekaligus perawi-perawinya.

\section{Motivasi Pengutipan Hadis Pendidikan}

Motivasi yang melatarbelakangi pengutipan hadis dalam tesis dan skripsi tentang pendidikan di Unipdu Jombang bisa dibagi menjadi dua, yaitu motivasi internal dan motivasi eksternal. Motivasi internal muncul dari dalam diri mahasiswa sendiri walaupun mungkin ada keterkaitan dengan pengaruh eksternal. Sedangkan motivasi eksternal muncul dari luar diri mahasiswa walaupun mungkin ada keterkaitan dengan pengaruh internal.

Ada empat motivasi internal yang melatarbelakangi pengutipan hadis dalam tesis dan skripsi tentang pendidikan Islam. Pertama,

${ }^{44}$ Muhammad Muștafā al-A'ẓami, Manhaj al-Naqd inda al-Muḥaddithīn (Arab Saudi: Maktabat al-Kawthar, 1990), 5. 
keyakinan bahwa hadis adalah sumber ajaran Islam kedua setelah Alquran, termasuk pendidikan Islam, baik pendidikan formal maupun pendidikan informal. Para pengutip hadis pendidikan umumnya meyakini bahwa konsep dan sistem pendidikan Islam yang ada bisa dan seharusnya didasarkan pada Alquran dan Hadis. Mengingat, salah satu fungsi Rasulullah adalah untuk mendidik umat Islam di manapun dan kapanpun. Salah satu pengutip hadis pendidikan yang berinisial DW menyatakan, "Hadis adalah sumber kedua dalam Islam setelah Alquran, maka sudah sepantasnya jika kita berbicara tentang pendidikan Islam untuk mendasarkannya pada Alquran dan Hadis." Kedua, kesadaran terhadap adanya kesesuaian antara konsep dan sistem pendidikan Islam, baik formal maupun informal, dengan hadis. Kesesuaian itu ada pada hadis-hadis yang dianggap mengandung nilainilai pendidikan Islam. Asalkan dipahami secara kontekstual dan mendalam, para pengutip hadis pendidikan percaya bahwa konsep dan sistem pendidikan Islam bisa dikaitkan dengan nilai-nilai pendidikan yang terkandung dalam hadis. Kontekstualisasi pemahaman di sini merupakan keniscayaan sebab konteks hadis terjadi lebih dari 14 abad yang lalu. Salah satu pengutip hadis pendidikan yang berinisial SAH menyatakan, "Saya mengutip salah satu hadis yang berkaitan dengan kewajiban pendidik untuk memperhatikan kondisi psikologis peserta didik."

Ketiga, kecenderungan legalisasi konsep atau sistem pendidikan Islam yang ada berdasarkan teks hadis. Pembenaran yang berangkat dari teks keagamaan memang diakui efektif dalam mengarahkan kelompok masyarakat yang bersifat religius. Program Studi S1 Pendidikan Agama Islam dan S2 Manajemen Pendidikan Islam di Unipdu Jombang adalah lingkungan mahasiswa yang religius, minimal secara formal demikian. Tidak mengherankan jika kemudian dalam tesis dan skripsi mahasiswa ditemukan teks-teks keagamaan berupa ayat-ayat Alquran, hadis-hadis Nabi, hingga kata-kata mutiara sahabat, tabiin atau ulama. Salah satu pengutip hadis yang berinisial FH mengaku, "Saya mengutip hadis 'perintahlah anak-anak kalian salat pada umur tujuh tahun dan pukullah mereka sebab meninggalkan salat pada umur sepuluh tahun' untuk menekankan bahwa pukulan yang tidak menyakiti itu bisa saja diterapkan dalam pendidikan." Keempat, pengaruh latar belakang pendidikan mahasiswa. Berdasarkan data administratif di Fakultas Agama Islam pada Program Studi Pendidikan Agama Islam, 80\% mahasiswa mempunyai 
latar belakang pendidikan Madrasah Aliyah (MA), selebihnya mempunyai latar belakang selain MA. Jadi sebelumnya para mahasiswa pengutip hadis memang sudah berada di lingkungan pendidikan Islam yang tidak jauh dari teks-teks keagamaan, terutama ayat-ayat Alquran dan hadis-hadis Nabi.

Di samping empat motivasi internal di atas, pengutipan hadis pendidikan juga dilatarbelakangi oleh enam motivasi eksternal. Pertama, pengaruh pimpinan Yayasan dan Universitas. Pimpinan universitas, yang ada di tingkat Yayasan dan Rektorat mempunyai andil signifikan dalam pengutipan hadis pendidikan. Berdasarkan observasi terbatas pada setiap pidato atau sambutan di depan mahasiswa dalam berbagai kesempatan, pimpinan Yayasan dan Universitas biasanya membumbui pidato atau sambutan dengan ayatayat Alquran dan hadis-hadis Nabi, terutama tentang kewajiban dan urgensi menuntut ilmu pengetahuan. Kedua, dorongan dosen bidang Alquran dan Hadis. Sama halnya dengan para pimpinan Yayasan dan Universitas, para dosen yang mengampu matakuliah bidang Alquran dan Hadis juga mempunyai pengaruh signifikan dalam pengutipan hadis pendidikan, terutama para dosen pengampu matakuliah Tafsir Tarbawi dan matakuliah Hadis Tarbawi. Berdasarkan wawancara dengan para pengutip hadis pendidikan, ketika ditanya apakah pengutipan hadis pendidikan terinspirasi oleh para dosen, rata-rata mereka menegaskan bahwa sejumlah dosen bidang Alquran dan Hadis berkata bahwa "skripsi Pendidikan Agama Islam di Unipdu seharusnya ada ayat Alquran atau hadis Nabi, supaya ada perbedaan antara jurusan Pendidikan Agama Islam di kampus pesantren dengan jurusan Pendidikan umum di luar sana."

Ketiga, pengaruh matakuliah Ayat dan Hadis Pendidikan dan matakuliah Hadis Tarbawi. Di banding signifikansi pengaruh motivasi-motivasi lainnya, matakuliah Ayat dan Hadis Pendidikan dan matakuliah Hadis Tarbawi mempunyai andil paling signifikan dalam pengutipan hadis pendidikan. Dilihat dari judul matakuliahnya, "tarbaw " mempunyai arti "yang bersifat pendidikan." Hadis-hadis yang dikutip dalam tesis dan skripsi rata-rata merupakan materi yang disajikan dalam dua matakuliah tersebut. Berdasarkan studi dokumen jurnal-jurnal perkuliahan dua matakuliah ini, materi pada setiap tatap muka perkuliahan tidak jauh dari tema tujuan pendidikan, kewajiban belajar, materi pendidikan, metode pembelajaran, media pembelajaran, dan seterusnya. Seluruh materi itu dikaitkan dengan hadis, misalnya 
tujuan pendidikan dalam hadis, kewajiban belajar dalam hadis, dan seterusnya. Keempat, pengaruh buku-buku yang bertema hadis tarbawi. Di pasaran banyak beredar buku-buku yang bertema tentang hadis pendidikan, di antara yang paling populer adalah buku Hadis Tarbawi: Hadis-Hadis Pendidikan yang ditulis oleh Abdul Madjid Khon. Buku-buku itu adalah salah satu referensi utama yang harus ditelaah oleh para calon penulis tesis dan skripsi tentang pendidikan Islam. Berdasarkan studi dokumen dalam bentuk arsip tesis dan skripsi tentang pendidikan Islam yang ditulis pada tahun 2017, ditemukan sejumlah hadis yang tidak dirujukkan kepada sumber asli hadis, melainkan dirujukkan kepada buku-buku hadis tarbawi. Studi arsip tesis dan skripsi itu menunjukkan bahwa banyak penulis tesis dan skripsi yang sudah merasa puas dengan membuka buku-buku hadis tarbawi $\bar{i}$ tanpa diimbangi dengan membuka literatur-literatur yang menjadi sumber asli hadis dan sumber primer perujukan, penilaian dan pemahaman hadis.

Kelima, pengaruh buku-buku pendidikan Islam. Meskipun tidak secara spesifik membahas hadis pendidikan, buku-buku yang bertema pendidikan Islam terkadang juga dihiasi sejumlah ayat dan hadis yang dianggap relevan dengan topik pendidikan yang sedang dibahas. Salah satu yang paling populer adalah buku Metodologi Penelitian Pendidikan Islam yang ditulis oleh Imam Bawani. Keenam, terakhir, pengaruh arsip tesis dan skripsi tentang pendidikan Islam. Hampir seluruh mahasiswa yang hendak menulis tugas akhir pasti menelaah arsip tugas akhir yang ditulis oleh mahasiswa yang sudah lulus untuk, terutama, sekadar mengetahui alur penulisan tugas akhir yang baik dan benar. Dalam tugas akhir mahasiswa Program Studi Pendidikan Agama Islam dan Manajemen Pendidikan Islam tentunya juga dihiasi sejumlah hadis yang dianggap relevan dengan topik pendidikan yang sedang dikaji. Dari situlah kecenderungan untuk mengutip hadis pendidikan bisa dimulai. Salah satu pengutip hadis yang berinisial SNN mengaku, "supaya memperoleh panduan konkret, Saya rajin pergi ke perpustakaan untuk menelaah skripsi tentang pendidikan Islam.”

\section{Eksistensi Hadis Pendidikan}

Berdasarkan studi dokumen dalam bentuk arsip tesis dan skripsi di Unipdu Jombang, dari kurun waktu 3 tahun terakhir yang menjadi objek penelitian ini, dari tahun 2015 hingga 2017, terdapat 105 tesis 
tentang manajemen pendidikan Islam. Dari ke-105 tesis yang ada itu, terdapat 41 hadis yang disebutkan dalam 22 tesis, tepatnya sebagai landasan teoritis di bab 2. Jika dirata-rata, bisa dinyatakan bahwa lebih dari sekitar 1 dari 3 tesis tentang manajemen pendidikan Islam menyebutkan 1 hadis. Berdasarkan skripsi tentang pendidikan agama Islam yang diujikan pada tahun 2017, yang berjumlah 109, terdapat 62 hadis yang disebutkan dalam 22 skripsi. Sebagaimana 41 hadis yang disebutkan dalam tesis, 62 hadis dalam skripsi itu disebutkan sebagai landasan teoritis di bab 2. Jika dirata-rata, bisa dinyatakan bahwa 1 dari 2 skripsi tentang pendidikan agama Islam menyebutkan 1 hadis. Jika diakumulasikan, terdapat 214 karya ilmiah sebagai tugas akhir mahasiswa dalam bentuk tesis dan skripsi tentang manajemen pendidikan Islam dan pendidikan agama Islam. Dalam 214 karya ilmiah itu terdapat 103 hadis yang umumnya disebutkan sebagai landasan teoritis di bab 2. 103 hadis itu disebutkan dalam 44 karya ilmiah. Jika dirata-rata, bisa dinyatakan bahwa kira-kira setiap 1 dari 2 karya ilmiah menyebutkan 1 hadis.

Dari 103 hadis yang disebutkan dalam karya ilmiah di atas, tidak seluruhnya dirujukkan sebagaimana mestinya. Pengutipan sebagaimana mestinya di sini merujuk pada teknik takbrij hadis yang ada dalam ilmu hadis. Bentuk pengutipan dan perujukan 103 hadis yang ada itu bisa dijelaskan dalam 6 bentuk pengutipan dan perujukan, sebagai berikut. Pertama, 9\% dari jumlah total hadis dirujukkan secara ideal-sederhana, atau sebagaimana mestinya. Yang dimaksud perujukan hadis secara ideal-sederhana di sini adalah, merujukkan hadis sesuai kaidah takbrij untuk kepentingan pengutipan, bukan penelitian. Para pengutip 9\% dari jumlah total hadis itu menyebutkan nama penulis hadis, misalnya al-Bukhāri; judul kitab hadis, misalnya

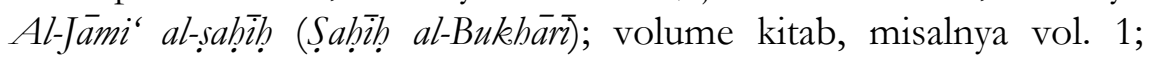
nomor hadis, misalnya no. 1. Rangkaian itu membentuk: al-Bukhāri,

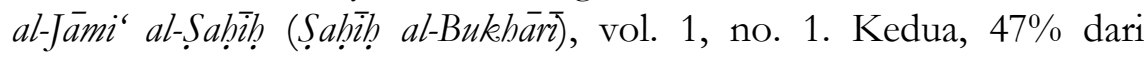
jumlah total hadis dirujukkan secara tidak spesifik. Ketidakspesifikan itu biasanya ada pada judul kitab hadis, volume hadis dan nomor hadis. Para pengutip 47 dari jumlah total hadis itu biasanya hanya menyebutkan nama penulis hadis atau judul kitab hadis, tanpa menyebutkan volume kitab dan nomor hadis. Misalnya, para pengutip hadis hanya menulis: "HR al-Bukhāri Muslim," atau "HR Ṣạ̣ị̧ alBukhäri." 
Ketiga, 10\% dari jumlah total hadis dirujukkan secara tidak akurat. Yang dimaksud dengan ketidakakuratan di sini adalah ketidaksesuaian antara identitas rujukan hadis dengan realitasnya. Para pengutip $10 \%$ dari jumlah total hadis itu kurang teliti atau bahkan bersikap abai dalam merujukkan hadis. Misalnya, pengutip merujukkan satu hadis pada al-Bukhäri dalam Al-Jämi' al-sahịị; setelah ditelusuri, ternyata hadis itu tidak ditemukan dalam kitab itu, melainkan ditemukan dalam kitab lain, Șaḩị Muslim misalnya. Keempat, 29\% dari jumlah total hadis dirujukkan pada non-sumberasli hadis. Dengan kata lain, para pengutip 29\% dari jumlah total hadis itu tidak merujukkan hadis pada kitab-kitab hadis yang terhitung sebagai sumber asli hadis, semacam kitab hadis, kitab sejarah, kitab biografi, kitab Ilmu Hadis, kitab tafsir, dan semacamnya, yang penulisnya menyebutkan hadis dengan sanad miliknya. Melainkan, para pengutip hadis merujukkan hadis kepada selain sumber asli hadis, semacam buku paket sekolah, buku teks kuliah, buku referensi, jurnal ilmiah, dan semacamnya.

Kelima, 21\% dari jumlah total hadis dikutip terjemahannya sehingga pelacakan dan perujukan sulit atau bahkan tidak bisa dilakukan. Pelacakan dan penelusuran hadis, baik memanfaatkan perangkat lunak (software) maupun dengan cara takbrij klasik, bisa dilakukan dengan mudah apabila hadis itu ditulis dalam huruf Arab atau ditulis dengan transliterasi Arab-Indonesia standar. Di samping itu, terjemahan hadis yang tidak disertai dengan teks aslinya berpotensi lebih besar terjadi bias penerjemahan sehingga pelacakan sulit dilakukan. Keenam, 5\% dari jumlah total hadis disebutkan tanpa rujukan. Dalam tradisi Ilmu Hadis, hadis yang disebutkan tanpa rujukan akan menimbulkan berbagai pertanyaan kritis: benarkah itu hadis Nabi? Siapa yang meriwayatkan? Kitab apa yang menyantumkannya? Pertanyaan-pertanyaan yang memang seharusnya dipertanyakan itu bisa dijawab dengan penerapan takhrij sederhana.

Dari 103 hadis yang disebutkan dalam karya ilmiah seperti dipaparkan sebelumnya, tidak seluruhnya bisa "diterima" (maqbūt). Penilaian hadis di sini berdasarkan analisis menggunakan pendekatan sistem sanad dan penilaian kredibilitas perawi (jarb wa ta'dii) yang ada dalam Ilmu Hadis. Nilai 103 hadis yang ada itu bisa dijelaskan dalam 6 bentuk pengutipan dan perujukan. Pertama, sebanyak 63\% dari jumlah total hadis bernilai sahih, dan sebanyak 3\% dari jumlah total hadis bernilai hasan. Kedua, sebanyak 3\% dari jumlah total hadis 
bernilai daif (lemah). Ketiga, sebanyak 3\% dari jumlah total hadis bernilai daif sekali (da î jiddan). Keempat, sebanyak 4\% dari jumlah total hadis bernilai palsu (mawdū $)$. Kelima, sebanyak 4\% dari jumlah total hadis termasuk dalam kategori pseudohadis. Keenam, sebanyak $17 \%$ dari jumlah total hadis tidak atau belum jelas penilaiannya.

Dari 103 hadis yang disebutkan dalam karya ilmiah seperti dipaparkan sebelumnya, tidak seluruhnya sesuai konteks, tidak seluruhnya interpretatif, dan tidak seluruhnya referensial. 103 hadis yang ada itu ada yang dicantumkan sesuai konteksnya dan ada yang dicantumkan tidak sesuai konteksnya, atau ada yang dipahami secara kontekstual dan ada yang dipahami secara tekstual; ada yang disertai interpretasi dan ada yang tidak disertai interpretasi sama sekali, alias untuk menguatkan dan mendukung suatu pernyataan saja. Bentuk pemahaman dan interpretasi 103 hadis itu bisa disederhanakan sebagai berikut. Pertama, dari segi pemahaman kontekstual dan nonkontekstual. Sebanyak $67 \%$ dari jumlah total hadis dipahami secara kontekstual dan sebanyak $36 \%$ dari jumlah total hadis dipahami secara nonkontekstual. Kedua, sebanyak 18\% dari jumlah total hadis disertai interpretasi dan $85 \%$ dari jumlah total hadis tidak disertai interpretasi. Ketiga, $0 \%$ dari jumlah total hadis yang disebutkan disertai referensi kitab syarah hadis dan $100 \%$ dari jumlah total hadis yang disebutkan tidak disertai referensi kitab syarah hadis.

\section{Problematika Pengutipan Hadis Pendidikan dan Solusinya}

Ketidaksesuaian antara realitas pengutipan hadis pendidikan dan standar pengutipan hadis perspektif Ilmu Hadis dalam tesis dan skripsi di Unipdu Jombang dilatarbelakangi oleh empat hal. Pertama, banyaknya referensi seputar hadis pendidikan (tarbawi $\bar{l}$ ) baik literatur fisik maupun online yang menyuguhkan pengutipan hadis yang tidak sesuai dengan standar pengutipan hadis perspektif Ilmu Hadis. Berdasarkan studi dokumen referensi fisik dan dokumen referensi online tentang hadis pendidikan, ditemukan banyak ketidaksesuaian antara antara realitas pengutipan hadis pendidikan dan standar pengutipan hadis perspektif Ilmu Hadis, terutama pada bentuk perujukan hadis. Di banding dengan referensi fisik, ketidaksesuaian dalam referensi online lebih signifikan baik secara kuantitas maupun kuantitas.

Kedua, banyaknya referensi seputar hadis pendidikan yang menyuguhkan pengutipan hadis yang tidak sesuai dengan standar 
pengutipan hadis perspektif Ilmu Hadis dilatarbelakangi oleh tiada atau kurangnya pemahaman terhadap Ilmu Hadis, khususnya kaidah takbrij. Pada Program Studi S2 Manajemen Pendidikan Islam dan Program Studi S1 Pendidikan Agama Islam Unipdu Jombang memang terdapat matakuliah Studi Hadis, namun hanya satu semester pertama. Tentunya matakuliah Studi Hadis itu sebatas pengetahuan umum yang tidak bisa membuat mahasiswa memperoleh pemahaman komprehensif tentang Ilmu Hadis. Realitasnya, Program Studi S2 Manajemen Pendidikan Islam dan Program Studi S1 Pendidikan Agama Islam bukan merupakan program studi yang menekuni Ilmu Hadis secara mendalam, sehingga ketidaksesuaian antara realitas pengutipan hadis pendidikan dan standar pengutipan hadis perspektif Ilmu Hadis yang ada di berbagai referensi tidak bisa atau sulit diidentifikasi. Ketiga, ketidakmampuan mengakses sumber asli hadis, kitab takhrij, dan kitab syarah. Ketidakmampuan mengakses sumber asli hadis, kitab takhrij, dan kitab syarah dilatarbelakangi oleh ketiadaan literatur-literatur tersebut di perpustakaan dan mahalnya biaya yang harus dikeluarkan untuk membelinya. Berdasarkan observasi langsung penulis ke perpustakaan Unipdu Jombang, tidak ditemukan literatur-literatur yang terhitung sebagai sumber asli hadis, kitab takhrij, dan kitab syarah. Di samping memang tidak terlalu dibutuhkan oleh mahasiswa Unipdu Jombang secara umum, literaturliteratur tersebut dalam bentuk fisik bisa menghabiskan dana yang tidak sedikit. Itu karena mayoritas literatur-literatur yang sedang dibahas ini tebal-tebal dan berjilid-jilid.

Keempat, perilaku abai terhadap ketidaksesuaian antara realitas pengutipan hadis pendidikan dan standar pengutipan hadis perspektif Ilmu Hadis. Perilaku abai ini merupakan konsekuensi tiga problem sebelumnya. Dilihat dari hasil studi dokumen dalam bentuk arsip tesis dan skripsi sebelumnya, terutama dalam hal perujukan hadis, terlihat bahwa para pengutip hadis umumnya masih bersikap tidak peduli terhadap standar pengutipan hadis. Akibatnya, banyak bentuk pengutipan hadis yang tidak bisa dipertanggungjawabkan, semisal pengutipan pseusohadis, hadis palsu, hadis daif sekali dan daif yang berkaitan dengan akidah dan hukum; serta pemahaman hadis yang tidak interpretatif dan referensial sehingga berpotensi terhadap pemahaman yang tekstual bahkan mungkin radikal.

Demikian problematika pengutipan hadis yang dihadapi oleh para pengutip hadis pendidikan. Dari sini, ada dua harapan yang bisa 
diproyeksikan sebagai jembatan untuk memecahkan problem pengutipan hadis pendidikan. Pertama, perkembangan teknologi dalam bentuk perpustakaan digital, dalam hal ini adalah perangkat lunak Maktabah Shämilah. Ini merupakan hal positif dan harapan yang diproyeksikan bisa mengatasi masalah ketidakmampuan mengakses sumber asli hadis, kitab takhrij, dan kitab syarah yang disebabkan oleh ketiadaan literatur-literatur tersebut di perpustakaan dan mahalnya biaya yang harus dikeluarkan untuk membelinya. Terbukanya akses kepada berbagai sumber asli hadis, kitab takhrij, dan kitab syarah lewat perangkat lunak Maktabah Shāmilah berdampak secara signifikan terhadap ketersediaan literatur-literatur yang bisa mengantarkan kepada pengutipan hadis pendidikan sesuai standar dan memangkas ketidaksesuain-ketidaksesuaian yang ada selama ini. Ketersediaan literatur-literatur yang bisa dimanfaatkan sebagai referensi pengutipan hadis sesuai standar menjadikan para pengutip hadis pendidikan mempunyai pegangan referensial yang komprehensif. Para pengutip hadis pendidikan yang mempunyai pegangan referensial yang komprehensif akan melenyapkan atau mengurangi perilaku dan sikap abai terhadap ketidaksesuaian antara realitas pengutipan hadis pendidikan dan standar pengutipan hadis perspektif Ilmu Hadis. Kedua, perkembangan pemikiran tentang pemahaman hadis juga merupakan hal positif dan harapan yang diproyeksikan dapat memangkas kesenjangan antara teks dan konteks yang akhirnya menjadi pemahaman kontekstual. Dalam hal ini adalah kontekstualisasi pemahaman hadis versi pemikiran Yüsuf al-Qaraḍāwi.

Dua perkembangan di atas, sekali lagi, adalah harapan yang bisa mengantarkan kepada solusi untuk problem pengutipan hadis pendidikan. Ketidaksesuaian antara realitas pengutipan hadis pendidikan dan standar pengutipan hadis perspektif Ilmu Hadis merupakan masalah yang harus diatasi sebab berpotensi terhadap dua hal negatif: pengutipan hadis yang tidak bisa dipertanggungjawabkan, semisal pengutipan pseusohadis, hadis palsu, hadis daif sekali dan daif yang berkaitan dengan akidah dan hukum; serta pemahaman hadis yang tidak interpretatif dan referensial sehingga berpotensi terhadap pemahaman yang tekstual bahkan mungkin radikal.

Implementasi standar pengutipan hadis persepktif Ilmu Hadis yang meliputi perujukan, penilaian dan proses pemahaman hadis pendidikan dilakukan dengan menyiapkan panduan praktis, teknis dan operasional tentang perujukan, penilaian dan proses pemahaman 
hadis pendidikan yang diwujudkan dalam bentuk buku Metode Studi Hadis Pendidikan dan Model Perujukan, Penilaian dan Proses Pemahaman untuk Antisipasi Ketidaksesuaian antara Realitas dan Standar Pengutipan Hadis Pendidikan. Ke depan, sebagai pendamping buku panduan dan model tersebut, diproyeksikan ketersediaan Aplikasi Hadis Tarbawi dan Manual Penerapan Metode Studi Hadis Pendidikan Berbasis Software Maktabah Shāmilah.

Implementasi standar pengutipan hadis persepktif Ilmu Hadis selanjutnya dilakukan dalam bentuk sosialisasi panduan praktis, teknis dan operasional tentang perujukan, penilaian dan proses pemahaman hadis pendidikan oleh pihak-pihak terkait, seperti Fakultas, Program Pascasarjana dan Program Studi. Implementasi standar pengutipan hadis persepktif Ilmu Hadis juga dilakukan dalam bentuk sosialisasi tentang dampak negatif pengutipan hadis pendidikan yang tidak sesuai dengan standar pengutipan hadis perpektif Ilmu Hadis, yang meliputi pengutipan hadis yang tidak bisa dipertanggungjawabkan, dan pemahaman hadis yang tidak interpretatif dan referensial sehingga berpotensi terhadap pemahaman yang tekstual bahkan mungkin radikal.

\section{Kesimpulan}

Dari paparan data dan analisisnya pada bab sebelumnya, bisa disimpulkan tiga poin, sebagai berikut. Pertama, motivasi yang melatarbelakangi pengutipan hadis dalam tesis dan skripsi tentang pendidikan di Unipdu Jombang bisa dibagi menjadi dua, yaitu motivasi internal dan motivasi eksternal. Ada empat motivasi internal yang melatarbelakangi pengutipan hadis dalam tesis dan skripsi tentang pendidikan Islam, yaitu keyakinan bahwa hadis adalah sumber ajaran Islam kedua setelah Alquran, termasuk pendidikan Islam, baik pendidikan formal maupun pendidikan informal; kesadaran terhadap adanya kesesuaian antara konsep dan sistem pendidikan Islam, baik formal maupun informal, dengan hadis; kecenderungan legalisasi konsep atau sistem pendidikan Islam yang ada berdasarkan teks hadis; pengaruh latar belakang pendidikan mahasiswa. Di samping empat motivasi internal di atas, pengutipan hadis pendidikan juga dilatarbelakangi oleh enam motivasi eksternal, yaitu pengaruh pimpinan Yayasan dan Universitas; dorongan dosen bidang Alquran dan Hadis; pengaruh matakuliah Ayat dan Hadis Pendidikan dan matakuliah Hadis Tarbawi; pengaruh buku-buku yang bertema hadis 
tarbaw $\bar{i}$; pengaruh buku-buku pendidikan Islam; pengaruh arsip tesis dan skripsi tentang pendidikan Islam.

Kedua, hanya $9 \%$ bentuk perujukan hadis yang sudah sesuai harapan, yaitu sesuai dengan standar takbrij sederhana. Namun, 91\% bentuk perujukan hadis tidak sesuai standar takbrij sederhana. Ditemukan $4 \%$ pseudohadis, $4 \%$ hadis palsu, dan $17 \%$ hadis yang belum jelas nilainya. Artinya, meskipun tidak dalam skala besar, penilaian hadis juga belum sesuai harapan, yakni masih ditemukan sejumlah hadis yang tidak otentik dan tidak valid. Sebanyak 36\% hadis dipahami tidak pada konteksnya, 85\% hadis dikutip tanpa interpretasi, dan $100 \%$ hadis dikutip tanpa didukung referensi syarah hadis. Artinya, pemahaman dan interpretasi hadis masih jauh dari harapan, yakni dikutip dan dipahami secara kontekstual, interpretatif dan referensial.

Ketiga, ketidaksesuaian antara realitas pengutipan hadis pendidikan dan standar pengutipan hadis perspektif Ilmu Hadis dalam tesis dan skripsi di Unipdu Jombang dilatarbelakangi oleh empat hal, yaitu banyaknya referensi seputar hadis pendidikan (tarbawñ) baik literatur fisik maupun online yang menyuguhkan pengutipan hadis yang tidak sesuai dengan standar pengutipan hadis perspektif Ilmu Hadis; banyaknya referensi seputar hadis pendidikan yang menyuguhkan pengutipan hadis yang tidak sesuai dengan standar pengutipan hadis perspektif Ilmu Hadis dilatarbelakangi oleh tiada atau kurangnya pemahaman terhadap Ilmu Hadis, khususnya kaidah takbrij; ketidakmampuan mengakses sumber asli hadis, kitab takhrij, dan kitab syarah. Ketidakmampuan mengakses sumber asli hadis, kitab takhrij, dan kitab syarah dilatarbelakangi oleh ketiadaan literatur-literatur tersebut di perpustakaan dan mahalnya biaya yang harus dikeluarkan untuk membelinya; perilaku abai terhadap ketidaksesuaian antara realitas pengutipan hadis pendidikan dan standar pengutipan hadis perspektif Ilmu Hadis.

Solusi untuk mengatasi problem-problem pengutipan hadis di atas adalah dengan mengimplementasikan standar pengutipan hadis persepktif Ilmu Hadis yang meliputi perujukan, penilaian dan proses pemahaman hadis pendidikan dilakukan dengan menyiapkan panduan praktis, teknis dan operasional tentang perujukan, penilaian dan proses pemahaman hadis pendidikan yang diwujudkan dalam bentuk buku Metode Studi Hadis Pendidikan dan Model Perujukan, Penilaian dan Proses Pemahaman untuk Antisipasi Ketidaksesuaian antara 
Realitas dan Standar Pengutipan Hadis Pendidikan. Ke depan, sebagai pendamping buku panduan dan model tersebut, diproyeksikan ketersediaan Aplikasi Hadis Tarbawi dan Manual Penerapan Metode Studi Hadis Pendidikan Berbasis Software Maktabah Shämilah. Implementasi standar pengutipan hadis persepktif Ilmu Hadis selanjutnya dilakukan dalam bentuk sosialisasi panduan praktis, teknis dan operasional tentang perujukan, penilaian dan proses pemahaman hadis pendidikan oleh pihak-pihak terkait, seperti Fakultas, Program Pascasarjana dan Program Studi. Implementasi standar pengutipan hadis persepktif Ilmu Hadis juga dilakukan dalam bentuk sosialisasi tentang dampak negatif pengutipan hadis pendidikan yang tidak sesuai dengan standar pengutipan hadis perpektif Ilmu Hadis, yang meliputi pengutipan hadis yang tidak bisa dipertanggungjawabkan, dan pemahaman hadis yang tidak interpretatif dan referensial sehingga berpotensi terhadap pemahaman yang tekstual bahkan mungkin radikal.

\section{Daftar Pustaka}

'Amrū (ibn), Ibn al-Ṣalāh 'Uthmān. Muqaddimat Ibn al-Salāḥ. Beirut dan Suriah: Dār al-Fikr dan Dār al-Fikr al-Mu'àșir, 1986.

'̄id (al), Ibn Daqiq. Al-Iqtirạ̄̄ fì Bayān al-Iștilāḥ. Beirut: Dār al-Kutub al-'Ilmiyah, t.th.

A'ẓami (al), Muhammad Muștafā. Manbaj al-Naqd ind al-Muhaddithin. Arab Saudi: Maktabat al-Kawthar, 1999.

Abnāsi (al). Al-Shadha al-Fayăh min 'Ulüm Ibn al-Ṣalāh. T.tp: Maktabat al-Rushd, 1998.

Abū Dāwud al-Sijistāni. Al-Sunan. Beirut: al-Maktabah al-'Aṣrìyah, t.th.

Ali, Nizar. "Kependidikan Islam dalam Perspektif Hadis Nabi." Jurnal Penelitian Agama, vol. 17, no. 1 (2008).

Amrulloh, Amrulloh. "Guru Sebagai Orang Tua dalam Hadis 'Aku Bagi Kalian Laksana Ayah'." Dirasat: Jurnal Manajemen dan Pendidikan Islam, vol. 2, no. 1 (2016).

- "Tawaran Komplementer Hadis Nabi untuk Gagasab 'The

Right Man on the Right Job': Penelusuran dan Pemahaman Hadis

'Idhā Wussida al-Amr ilā Ghayri Ablibi fa-Intaģir al-Sā'ah,"' Dirasat: Jurnal Manajemen dan Pendidikan Islam, vol. 1, no. 2 (2016).

Anșārì (al), 'Abd al-Awwal b. Hạmmād. Al-Majmū'. T.tp: t.p, t.th. 
Asni, Fathullah Al Haq Muhamad, Jasni Sulong dan Ammar Ismail. "Penggunaan Hadis Daif dalam Fatwa Mengenai Wasiat di Malaysia serta Langkah Penyelesaiannya." Journal of Hadith Studies, vol. 2, no. 1 (2017).

Baghdādi (al), al-Khațib. Al-Rị̣lah fi Ṭalab al-Hạadith, ed. Nūr al-Dīn 'Itr. Beirut: Dār al-Kutub al-'Tlmiyyah, 1975.

Bawani, Imam. Metodologi Penelitian Pendidikan Islam. Sidoarjo: Khazanah Ilmu, 2016.

Bayhaqii (al), Ahmmad b. al-Ḥusayn. Shu'ab al-Imān. Riyad: Maktabat alRushd, 2003.

Bayhaqi (al), Aḥmad b. al-Husayn. Al-Madkehal ila al-Sunan al-Kubrā. Kuwait: Dār al-Khulafä' li al-Kitāb al-Islāmi, t.th.

Biqa $\overline{\bar{c}}$ (al), Burhān al-Dīn. Al-Nukat al-Wafizyah bi Mà fì Sharḅ alAlfiyyah. T.tp: Maktabat al-Rushd, 2007.

Bukhārì (al), Muḥammad b. Ismā̄íl. Al-Jämi al-Ṣahịḥ. T.tp: Dār Tụu al-Najāh, $1422 \mathrm{H}$.

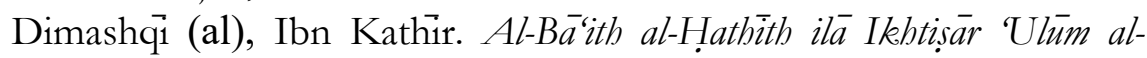
Hadith. Beirut: Dār al-Kutub al-'Ilmìnah, t.th.

Falah, Ahmad. Hadis Tarbawi. Kudus: Noura Media Enterprise, 2010. Fauziyah, Malihatul. "Takhrij Hadith dalam Buku Pendidikan Agama Islam dan Budi Pekerti Kurikulum 2013 SMP Kelas VII." Didaktika Religia: Jurnal Pendidikan Islam, vol. 2, no. 2 (2014).

Ford, David F. "Theology", dalam The Routledge Companion to the Study of Religion. Diedit oleh John R. Hinnells. New York: Routledge, 2005.

Hairudin. "Pendidikan Karakter Berbasis Sunnah Nabi." Jurnal alUlum: Jurnal Studi-Studi Islam, vol. 13, no. 1 (2013).

Hudaya, Hairul. "Prinsip-Prinsip Manajemen Pendidikan dalam Hadis." Al-Banjari: Jurnal Ilmiah Ilmu-Ilmu Keislaman, vol. 13, no. 2 (2014).

Ismail, M. Syuhudi. Kaidah Kesabihan Sanad Hadis: Telaab Kritis dan Tinjauan dalam Ilmu Sejarah. Jakarta: Bulan Bintang, 2005.

Jawiah Dakir dan Faisal Ahmad Shah. "A Contextual Approach in Understanding The Prophet's Hadith: An Analysis." Journal of Applied Science Research, vol. 8, no. 7 (2012).

Jum'ah, 'Imād 'Ali. Ușūl al-Takhrij wa Dirāsat al-Asānid al-Muyassarah. Riyad: Dār al-Nafà'is, 2004. 
Khāifah, Muḥammad Rashād. Madrasat al-Ḥadith fī Miss. Kairo: alHay'ah al-'Āmmah li Shu'ūn al-Matāabi' al-Amiriyah, t.th.

LP3M Unipdu Jombang. Buku Pedoman Penelitian dan Pengabdian Masyarakat. Jombang: Unipdu Press, 2014.

Ma'ruf, M. "Konsep Manajemen Pendidikan Islam dalam Alquran dan Hadis." Didaktika Religia: Jurnal Pendidikan Islam, vol. 3, no. 2 (2015).

Miles, Matthew B. dan A. Michael Huberman. Qualitative Data Analysis: An Expanded Sourcebook. London: Sage Publication, 1994.

Moleong, Lexy J. Metodologi Penelitian Kualitatif. Bandung: Rosda, 2013.

Mundhiri (al), 'Abd al-'Azịm b. 'Abd al-Qawi. Jawāb al-Ḥ̂fiz alMundhiri 'an As'ilah fi al-Jarh wa al-Ta'dīl. Halab: Maktabat alMațbu'àt al-Islämiyah, t.th.

Nasā̄ì (al), Aḥmad b. Shu'ayb. Al-Sunan al-Sughrā. Aleppo: Maktabat al-Matbū'àt al-Islāmiyah, 1986.

Nawawi (al), Muhy al-Dīn. Al-Taqríb wa-al-Taysìr li-Ma'rifat Sunan alBashìr al-Nadhì fi Ușül al-Ḥadìth. Beirut: Dār al-Kitāb al-'Arabi, 1985.

Nawawi (al), Yahyā b. Sharaf. Al-Majmū' Sharḥ al-Muhadhdhab. Beirut: Dār al-Fikr, 1985.

Nor, Zulhilmi bin Mohamed. "Metodologi al-Hạafiz Ibn al-Ṣalāh dalam Permasalahan Pentashihan Hadis dan Fenonemana Pentashihan dalam Masa Kini." Journal of Hadith Studies, vol. 1 (2016).

Pamil, Jon. "Takhrij Hadis: Langkah Awal Penelitian Hadis." Jurnal Pemikiran Islam, vol. 37, no. 1 (2013).

Prabowo, Yoga Sari. "Supervisi Pendidikan Agama Islam: Kajian Alquran dan Hadis." Edukasi: Jurnal Pendidikan Islam, vol. 3, no. 1 (2015).

Qaraḍāīi (al), Yūsuf. Kayfa Nata'malu ma'a al-Sunnah al-Nabawìyah. Kairo: Dār al-Shurūq, 2002.

Qazwinīi (al), Ibn Măjah. Al-Sunan. T.tp: Dār Ihyaā' al-Kutub al'Arabiyyah, t.th.

Ramle, Muhamad Rozaimi bin, Sahul Hamid bin Mohamed Maiddin dan Ahmad Zulfiqar Shah Abdul Hadi. "Fahm al-Hadith alSharif fi Dừi al-Siyāq al-Zamani wa al-Tarikhi." Journal of Hadith Studies, vol. 2, no. 1 (2017). 
Safian, Yasmin Hanani Mohd. "The Contribution of Yüsuf alQaradāiwi to the Development of Fiqh." Electronical Journal of Islamic and Middle Eastern Law, vol. 4 (2016).

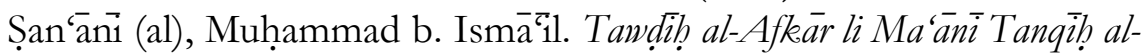
Anzāar. Beirut: Dār al-Kutub al-'Ilmìyah, 1997.

Stapa, Zakaria, Noranizah Yusuf dan Abdul Fatah Shaharudin. "Pendidikan Menurut Alquran dan Sunnah Serta Peranannya dalam Memperkasakan Tamadun Ummah." Jurnal Hadhari (2012).

Su'aidi, Hasan. “40 Hadis Pedoman NU Karya K.H. Hasyim Asy’ari: Studi Takhrij dan Analisis Konteks Sosial Keagamaan Berdirinya NU." Jurnal Penelitian, vol. 11, no. 1 (2014).

Sugiyono. Memahamai Penelitian Kualitatif. Bandung: Alfabeta, 2013.

Suryadilaga, Muhammad Alfatih. "Prospek Kajian Hadis di Perguruan

Tinggi Keagamaan Islam di Indonesia." Mutawatir Jurnal Keilmuan Tafsir Hadith, vol. 7, no. 1 (2017).

Suyūți (al), Jalāl al-Dīn. Tadrīb al-Rāwī fi Șharḅ Taqrīb al-Nawawì. T.tp: Dār Tỉibah, t.th.

Ṭaḥhān (al), Maḥmūd. Usūul al-Takhrij wa Dirāsăt al-Asānid. Riyad: Maktabat al-Ma árif, 1996. . Taysir Mustalah al-Hadith. T.tp: Maktabat al-Ma'arif, 2004.

Whaling, Frank. "Pendekatan Teologis", dalam Aneka Pendekatan Studi Agama. Diedit oleh Peter Connolly. Yogyakarta: Lkis, 2012. 